\title{
DEVELOPING AN' IDEAL GROWING STOCK FOR TOLERANT HARDWOODS IN CENTRAL ONTARIO ${ }^{1}$
}

\author{
By A. B. BERRY 2
}

\begin{abstract}
A brief history is given for a 47-acre woodlot successively high-graded for the best timber, grazed by cattle, cut haphazardly for fuelwood then placed under management with the object of developing a balanced stand structure for the maximum production of wood volume under the selection system. Four stem-distributions are being tested, two levels of growing stock and two upper diameter limits,combined with two cutting cycles. From the analysis of the results the best, or ideal, stand structure will be determined for this area.
\end{abstract}

\section{INTRODUCTION}

The Tree Farm Movement in Canada, and increased use of hardwoods by the wood-using industries, has stimulated interest in hardwood management, particularly on small forest holdings such as farm woodlots. A major problem in managing hardwoods, in particular the tolerant hardwoods, is what quantity of growing stock should be carried for the maximum growth of wood volume.

Although considerable research has been carried out on the growth and development of the tolerant hardwoods, no hard and fast rules can yet be formulated for managing such stands successfully under the selection system for the continuous production of wood at optimum stocking. There are two common concepts as to what constitutes optimum stocking. One is that stocking which will provide the greatest financial return (Duerr and Bond, 1952 and Duerr, 1960; p.124) and the other is that which will give the maximum continuous production of timber (Eyre and Zillgitt, 1950; and Paterson, 1958). These stocking values may not be the same, e.g., Zillgitt (1948) found that optimum stocking for financial return was less than that

for continuous yield and suggested that a stocking level between the two should provide both good growth and a satisfactory return on the investment.

The ultimate goal of forest management is usually to get maximum financial returns. However, since the financial aspects vary widely even within a forest region, it was decided to confine this study at the present time to determining the stocking and stem distribution that would provide maximum growth, designated in this paper as the "ideal" or "optimum" growing stock. From these stand attributes the financial optimum could then be deduced for a given set of economic conditions.

\footnotetext{
${ }^{2}$ Department of Forestry, Canada, Forest Research Branch Contribution No. 539.

${ }^{2}$ Research Officer, Forest Research Branch, Dept. of Forestry, Petawawa Forest Experiment Station, Chalk River, Ont.
} 


\section{Description and History of the ARea}

The Petawawa Forest Experiment Station is in the L.4c Section of the Great Lakes - St. Lawrence Forest Region (Rowe, 1959) and is located in Renfrew County, Ontario, midway between Ottawa and North Bay. The regional climate is continental and sub-humid.

The woodlot is situated on a low ridge orientated generally north-westsoutheast. Much of the area is almost level with the remainder on gentle slopes leading to shallow drainage channels that flow north out of the woodlot. The soil is brown podzolic loamy sand, derived from glacial till. It varies from shallow, over a bedrock of Precambrian granite, to at least five feet in depth and is characteristic of the Sherborne landtype (Hills, 1959). Most of the area has been classed (after Hills, 1952) as fresh, though locally it is moist or very moist.

\section{General Character of the WoOds}

Although 20 native tree species are growing on the area, only seven are of major importance (Table 1). The tolerant hardwoods (sugar maple, beech, yellow birch, red maple, and basswood) are the most abundant and account for approximately two-thirds of the total volume. ${ }^{3}$

Most of the stands are uneven-aged mixtures containing stems of all sizes from seedlings to mature trees 24 inches in diameter. The middle and upper storeys of the stands are usually mixtures of the tolerant hardwoods together with a few scattered stems of white pine, white spruce, white ash and white elm. Sugar maple is the main species in the young growth, although balsam fir and black ash occur on the moister areas.

The height-age data for sugar maple on the area indicate that its growth would be comparable to Plonski's (1960) Site Class 1 for tolerant hardwoods in Ontario and Westveld's (1933) Site Class 80 for sugar maple in the Lake States. Although the quality of the sugar maple is now poor, there are sufficient well-formed saplings to eventually produce good-quality sawlogs. However, the quality is not as good on this area as farther south where site and climate are more favourable.

\section{EARLy CUTTING}

Until 1904, the forest was high-graded for the best trees, cattle grazing damaged the reproduction, and eventually the forest comprised mostly overmature and defective trees of little commercial value. From 1904 to 1919 there was little or no cutting on the area. In 1919 it was reserved for the fuelwood supply of the Forest Experiment Station. Many cuts for fuelwood were made between 1919 and 1936, but no records were kept of the portions cut over or of the volumes removed.

From 1936 to 1956 an effort was made to manage the woodlot systematically. The area was divided into compartments of approximately equal size with one compartment being cut over each year. For the first decade the average annual allowable cut was set at 45 cubic feet per acre. For the second decade the allowable cut was increased to 69 cubic feet per acre, based on revised

\footnotetext{
${ }^{3}$ Botanical names of tree species are those used in "Native Trees of Canada", Dept. of Forestry
} Bulletin 61, 6th ed., 1961. 
estimates of growth. During the two periods the basic consideration in marking trees to be removed was to improve the quality of the growing stock by removing the poor quality trees and the less desirable species. Where a choice existed between species to be left the favoured species were yellow birch, basswood, white ash, white pine, sugar maple and white birch. Other species had no particular priority. No special efforts were made to ensure the development of an all-aged structure, nevertheless a reasonably well balanced stand structure was maintained (Figure 1), i.e. one which can be preserved and is characterized by a regular decrease in numbers of trees with an increase in diameter (Meyer, Recknagel, and Stevenson, 1952).

Despite the general principle of management being that the cut should approximate the growth, the volume per acre declined during the second decade (see Table 1). This reduction in growing stock resulted from overestimates of the growth rate and failure to allow for mortality. Actual annual growth was between 50 and 60 cubic feet per acre; and while it had been thought that mortality on a 10 -year cutting cycle would be negligible, it was in fact substantial.

Since previous inventories had proved to be unsatisfactory for both growth predictions and estimate of the growing stock, a series of $1 / 5$-acre permanent plots were established to sample about 30 per cent of the area of each compartment. The data from these sample plots will be used to determine stem distributions and also to compute growth rates.

\section{PlanNing an Ideal Growing Stock}

Until 1956, the main emphasis in managing the woodlot was on stand improvement and little consideration was given to the growing-stock level. Attention was then turned to developing an ideal or optimum distribution of tree sizes for two levels of growing stock, two cutting cycles, and two maximum sizes of crop trees.

The basic requirement of a single-tree selection forest is that trees of all ages (up to rotation age) be present. Since age-determination of all trees is impractical, tree size has been accepted in lieu of age. De Liocourt maintained that the stem-number distribution in a selection forest is a geometric progression with the number of stems decreasing at a constant rate from the smallest diameter class to the largest (Knuchel 1949, pp. 68-72). This principle has had wide, although not universal, acceptance. The stem-number distribution has also been found to vary with the site and species represented. For this study, however, de Liocourt's concept of a selection forest has been accepted and the main objective is to determine the ideal growing stock for tolerant hardwoods to be carried on the area after cutting.

For a given site and cover type, many balanced structures are possible. A balanced structure is that from which the annual growth can be removed without destroying the stand structure and lowering initial volume of growing stock. A stand may, however, have a balanced structure and still be understocked. The problem is to select a balanced structure that gives the ideal growing stock for the site and cover type. 


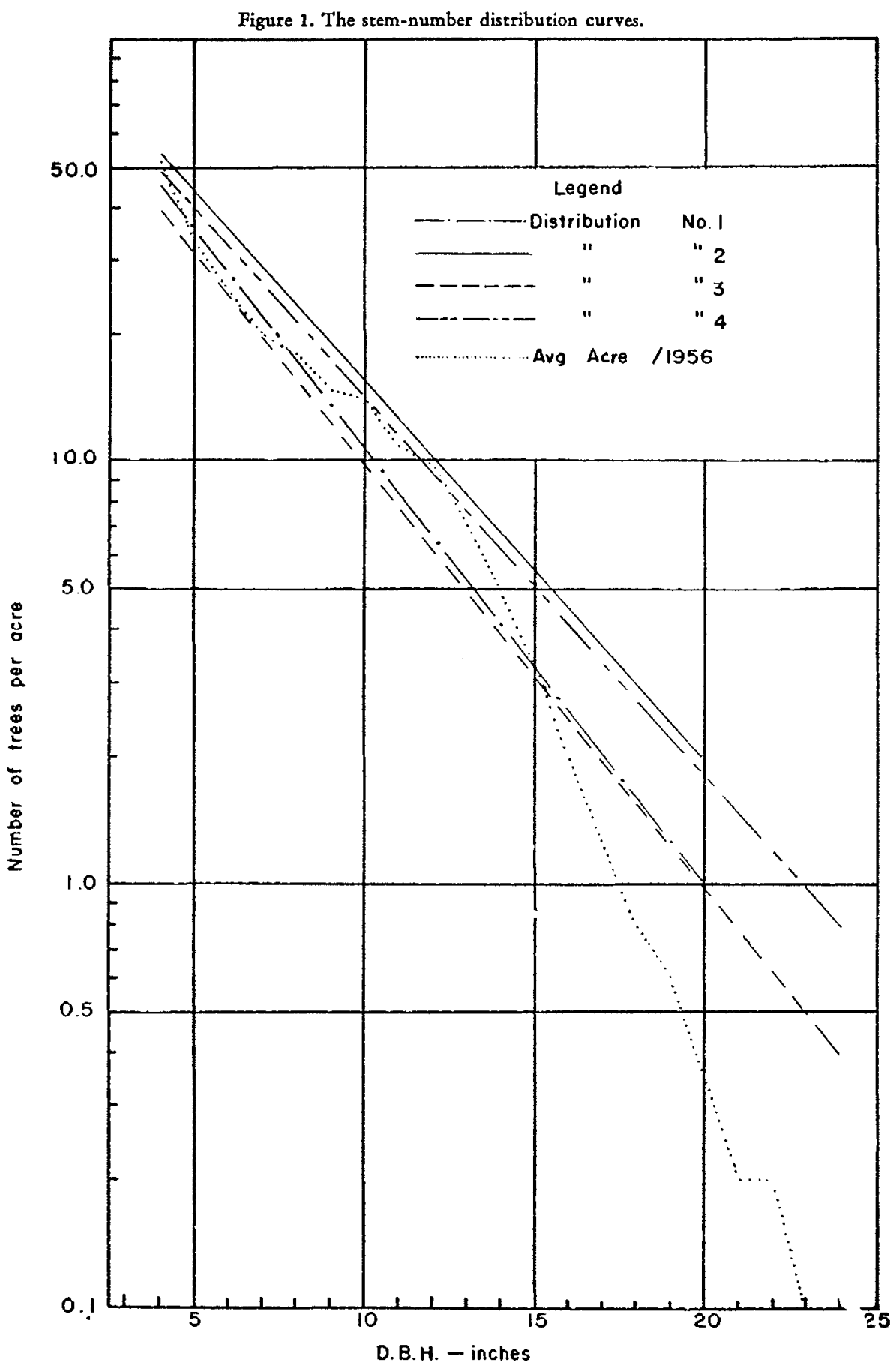


TABLE 1

The Number and Total Volume (Stump and Top Included) PER ACRe OF TREes 3.6 INCHES D.B.H. AND UP, AS SHOWN BY THE 1936, 1946, AND 1956 INVENTORIES

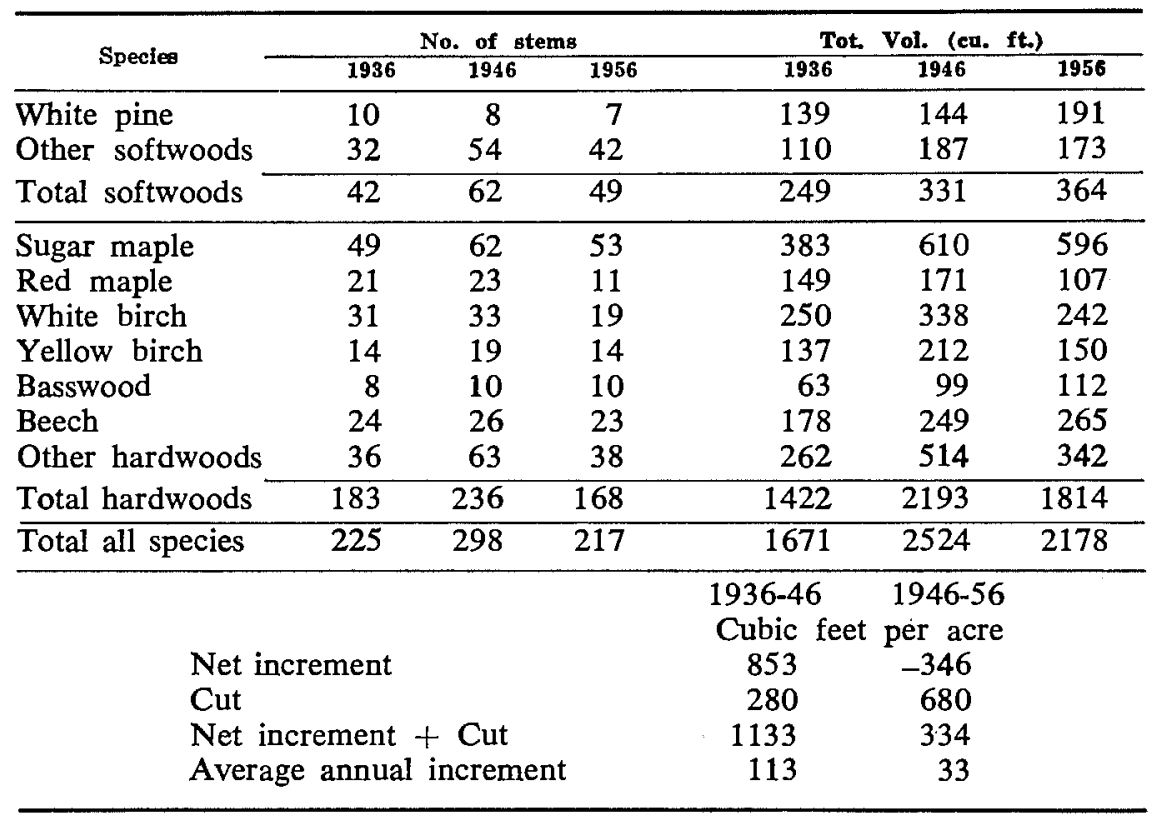

\section{Growing-stock Level}

The density of the stand is a very important consideration in establishing a balanced stand structure as too dense a stand retards the establishment of regeneration and too open a stand results in a surplus of the small size classes. In either case the even movement of trees from one diameter class to the next is disrupted and the form of the all-aged forest is destroyed.

To determine the ideal density, two volumes of 2,000 and 3,000 cubic feet per acre were selected. Past experience on the woodlot had shown that volumes of these magnitudes could be maintained without destroying the stand structure. The higher volume is in line with a volume of an all-aged tolerant hardwood forest as deduced from Plonski's (1960) normal yield tables for Ontario.

The volumes selected are also in agreement with those suggested by other investigators. For example Gilbert and Jensen (1958) recommended for tolerant hardwoods in the Northeast States a stand with a residual basal area of 80 square feet per acre trees 6 inches d.b.h. and larger; local volume tables give a volume of 2,200 cubic feet per acre for this stand. Similarly Arbogast (1957), for northern hardwoods in the Lake States, recommended a distribution having a residual basal area of 92 square feet and a volume of 
2,300 cubic feet per acre. Meyer (1952) advocated a volume of between 2,000 and 4,000 cubic feet for tolerant hardwood in Pennsylvania: the lower volumes for the production of pulpwood and the higher volumes for the production of sawlogs.

\section{Upper Size Limit}

Another major factor in determining the ideal balanced distribution is the maximum size tree to grow. If the tree is retained too long the growth rate will be so slow that loss in production will result, whereas if the tree is cut too soon valuable growth will be lost. From the limited data available from sample plots, cull studies (Morawski, Basham, and Turner, 1958) and normal yield tables (Plonski, 1960), it appears that the largest sized tree that can be grown without loss of volume growth, is between 20 and 24 inches in this area. In larger trees nearly 50 per cent of the merchantable growth of sugar maple is cull and the merchantable growth rates for yellow birch and beech show a marked decline.

The two diameters mentioned above were therefore selected as the upper diameter limits for this study. In setting these limits it was realized that at least two decades would elapse before enough trees of these sizes would be growing on the area owing to a present deficiency in trees over 17 inches.

\section{Cutting Cycle}

To determine what effect, if any, the length of the cutting cycle would have on growth, cutting cycles of 5 and 10 years were selected in combination with the two levels of growing stock and each of the two maximum croptree diameters. A longer cutting cycle than 10 years was not used because the longer the cutting cycle the less the forest would resemble a single-tree selection forest; a minimum of 5 years was chosen because it would probably not be economical to make smaller more frequent cuts.

\section{Stem-number Distribution}

With the volumes and upper diameter limits settled the next step was to derive the four balanced stem-number distributions based on available data for the cover type and site. Inventory and sample plot data indicated that acceptable stem distributions would encompass the following:

1. Between 180 and 215 trees per acre (trees 4 inches and larger) for a growing stock of 2,000 cubic feet, and 240 to 280 trees for 3,000 cubic feet.

2. Between 40 and 55 trees in the 4-inch d.b.h. class for both growing stock levels.

3. A minimum of 1 tree per acre where the maximum diameter was 20 inches and 0.4 trees where the maximum diameter was 24 inches.

With these criteria as a guide, the four stem-number distributions were derived and curves drawn (Figure 1). These distributions have more trees in the lower diameter classes than those suggested by Arbogast (1957) and Gilbert and Jensen (1958) because of the method of deriving them. In the approach used here, the distribution will form a geometric progression whereas the authors cited derived their distributions from empirical data which do not form true geometric progressions with a constant rate of diminution from one diameter class to the next. 
Hough (1954) has suggested a method of achieving a balanced distribution best fitted to produce the maximum timber possible for the site but as Smith (1962) has pointed out in a trial and error method several rotations may elapse before the balanced distribution is achieved and proved. In this study by setting up four provisional distributions and making an analysis of the growth patterns it is expected that the desired growing stock level and stem distributions can be determined in a much shorter time.

\section{Derivation of the Distribution Curves}

Two methods were used to derive the four stem distributions:

(1) For Distributions 1 and 2, available data and trial distributions indicated that acceptable distributions would contain 1.0 stems and 2.0 stems respectively in the 20-inch diameter class. The next step was to plot distribution curves on semi-logarithmic paper and adjust them until the total volume of the stems making up the distributions was approximately the same as the required volume. The number of stems in the upper diameter class was held constant for each of the two distributions as adjustments were made to the curves.

Plotting the curve on semi-logarithmic paper eliminates computing the number of stems in each diameter class of the geometric progression as the curves plot as straight lines and the values are read directly from the curve. In adjusting the curve a new straight line is drawn through the point on the graph designating the number of stems in the upper diameter class. The slope of the new line is altered to increase or decrease the volume as required. The slope of the line representing Distribution 1 was 1.27 and that for Distribution 2 was 1.23. Although this may appear to be a laborious process, the required distribution curve can be drawn on the third or, at most, the fourth attempt.

(2) A different method was used in deriving Distributions 3 and 4 as it was evident from available information and trial curves that the number of stems in the 24-inch diameter class would probably be less than one per acre. Consequently the problem was to derive suitable distributions with no point predetermined.

In constructing both curves, the geometric progression formula, $1=a r^{n-1}$, was used where:

$1=$ the number of stems in the smallest diameter class

$\mathrm{a}=$ the number in the largest diameter class

$r=$ the coefficient of diminution

$\mathrm{n}=$ the number of diameter classes in the progression

Trial distributions showed that for Distribution 3 the number of stems in both the largest and smallest diameter classes would be very close to the minimum numbers specified. With the minimum numbers of 0.4 and 40 stems, the equation was solved for " $r$ " and found to be 1.26. The entire distribution was then calculated. To do this the number in the 24-inch diameter class was multiplied by the coefficient of diminution to give the number in the 23 -inch class. This procedure was continued until the numbers of stems for each diameter class were calculated. The total volume of trees in this distribution was calculated and found to be 2,031 cubic feet. The next step was to multiply the number of stems in each diameter class by the 
factor $\frac{2.000}{2.031}$ thus producing a distribution of stems having a volume of approximately 2,000 cubic feet per acre.

For Distribution 4 it was evident that the numbers of stems would be near the maximums specified. Consequently as a base from which to start, the number of stems for the 4-inch and the 24-inch diameter classes were set at 55.0 and 0.9 respectively. The final distribution was derived in the same manner as Distribution 3 and the slope of the line (" $r$ ") was found to be 1.23.

\section{Applying the Curves}

The stem-distribution to be aimed for on each compartment was determined from a comparison of the actual distribution of the compartments with the provisional distributions. In general, the compartments selected to carry the growing stock of 3,000 cubic feet per acre were those having the highest present growing stock. The present growing stocks must be increased by 800 to 1,000 cubic feet per acre to attain this objective and an additional period will be necessary to bring about the desired distribution. For the compartments designated to carry the lesser growing stock, the main consideration is in moulding the stand structure to that which is desired, as the present growing stock is reasonably close to the specified 2,000 cubic feet per acre. The growing stocks on these latter compartments should approach that desired much sooner that those on the other compartments.

The stem-number distribution curves are a useful guide in managing a forest under the selection system. (The tally of stems is condensed to give the number of stems by size classes and then plotted.) The comparison of the actual distribution with the calculated indicates the diameter classes in which cutting should be concentrated to produce or retain the general stand structure desired.

This does not mean that the main objective is to attain the desired distribution without considering the silvicultural requirements of the stand. Spacing, tree vigour and relative importance of species must still be taken into account. The ideal stem-distribution is only a guide in determining which diameter classes are to be given particular attention where a choice exists between trees to be removed and trees to be left.

Two important points about the forest not revealed by the stem-number distributions are:

1. Whether there are sufficient seedlings and saplings to perpetuate the desired stand structure and volume production; and

2. The actual distribution of stems on the ground. The average distribution may appear to be satisfactory but the stand may be composed of small blocks of even-sized trees rather than an intimate mixture of all sizes.

In practice it is unlikely that the ideal distribution could be attained, or maintained exactly if it were attained. The varying rates of growth of the different species would make it virtually impossible to perpetuate a stand structure that has a constant diminution of numbers of stems from one size class to the next. Nevertheless, the general form of a selection forest can be maintained by operating on the basis of grouped diameter classes, instead of individual diameter classes, provided that an appropriate relationship is main- 
tained between small, medium and large trees (Meyer, Recknagel and Stevenson, 1952).

\section{SOMMAIRE}

La place d'étude de 47 acres faisait autrefois partie des boisés de fermes avoisinantes. La forêt était de haute qualité, mais les bestiaux pouvaient y paître, ce qui a baissé la qualité du bois sur pied. L'exploitation de cette étendue a été d'abord entreprise en 1936 en vue d'en tirer du bois de chauffage et du bois de sciage. Jusqu'en 1956, on y a pratiqué un cycle de coupes de dix ans, c'est-à-dire qu'on en bûchait une partie chaque année. Il s'agissait principalement de coupes d'amélioration. Les volumes de bois abattu correspondaient à l'accroissement prévu durant le cycle; mais l'accroissement réel a été plus faible que celui qui avait été prévu, ce qui a donné lieu à une diminution du volume sur pied.

Les résultats obtenus jusqu'ici ont démontré qu'il est facile de maintenir un peuplement inéquienne de feuillus tolérants. Ces données concordent avec celles de Meyer (1952) qui avait constaté dans une forêt de charmes, d'érables, de bouleaux et de pruches du New Hampshire, que la composition du peuplement demeure à peu près inchangée au cours de plusieurs décennies. On a également constaté que, sauf lorsqu'elle était modifiée de propos délibéré, la composition en essences restait la même, ce qui laisse croire que ces types de peuplement ont probablement très peu tendance aux changements majeurs de composition en essences.

Le taux de croissance s'est échelonné entre 50 et 60 pieds cubes à l'acre par année pour un volume sur pied d'environ 2,000 pieds cubes. Il est permis de présumer qu'à la suite d'une exploitation intensive, l'accroissement annuel pourrait être accru d'au moins 75 pieds cubes à l'acre.

L'auteur expose les projets futurs. Le but immédiat est la formation d'un peuplement équilibré qui produira une quantité maximum de bois grâce au jardinage. Quatre répartitions provisoires des fûts ont été mises au point; elles sont fondées sur des niveaux de volume sur pied de 2,000 à 3,000 pieds cubes à l'acre et sur deux limites supérieures de diamètre (20 et 24 pouces). L'auteur présume qu'il est possible de déterminer la densité de peuplement à l'acre qui assure le mieux une production soutenue de billes de bonne qualité, ainsi que le maximum de rendement.

\section{REFERENCES}

ARBOGAST, CARL Jr. 1957. Marking guides for northern hardwoods under the selection system. U.S.D.A. Lake States For. Exp. Sta., Sta. Pap. No. 56.

DUERR, W. A. 1960. Fundamentals of forestry economics. McGraw-Hill Book Co. Inc., New York, xii $+579 \mathrm{p}$

DUERR, W. A. and W. E. Bond. 1952. Optimum stocking of a selection forest. J. For. 50:12-16. EYRE, F. H. and W. M. Zilligitt. 1950. Size class distribution in old-growth northern hardwoods twenty years after cutting. U.S.D.A. Lake States For. Exp. Sta., Sta. Pap. No. 21.

GILBERT, Adrian and Victor S. JENSON. 1958. A management guide for northern hardwoods in New England. U.S.D.A. Northeast For. Exp. Sta., Sta. Pap. No. 112.

HILLS, G. A. 1952. The classification and evaluation of site for forestry. Ontario Dept. Lands and Forests, Div. of Res., Res. Rep. No. 24.

HILLS, G. A. 1959. A ready reference to the description of the land of Ontario and its productiviry. Ontario Dept. Lands and Forests, Div. of Res. 
HOUGH, A. F. 1954. The control method of forest management in an age of aerial photography. J. For. 52:568-574

KNUCHEL, Herman. 1949. Planning and control in the managed forest. Translated by Mark L. Anderson, 1953. Oliver and Boyd, Edinburgh. xvi +360 p.

MEYER, H. Arthur. 1952. Structure, growth, and drain in balanced unevenaged forests. J. For. 50:85-92.

MEYER, H. A., A. B. RECKNAGEL, and D. D. STEVENSON. 1952. Forest Management. The Ronald Press Co., New York. xii +290 .

MORAWSKI, Z. J. R., J. T. BASHAM and K. B. TURNER. 1958. A survey of a pathological condition in the forests of Ontario. Ontario Dept. Lands and Forests, Div. of Timber, Report No. 25.

PATERSON, D. B. 1958. A study of stand structure and management of irregular forests. Univ. Edinburgh, Forestry Dept., Bull. No. 5.

PLONSKI, W. L. 1960. Normal yield tables for black spruce, jack pine, aspen, white birch, tolerant hardwoods, white pine, and red pine for Ontario. Ontario Dept. Lands and Forests, Silv. Series, Bull. No. 2.

ROWE, J. S. 1959. Forest regions of Canada. Canada, Dept. Northern Affairs and National Resources, Forestry Branch, Bull. No. 123.

SMITH, D. M. 1962. The practice of silviculture. 7th ed. John Wiley and Sons, Inc., New York, viii $+578 \mathrm{p}$.

WESTVELD, R. H. 1933. The relation of certain soil characteristics to forest growth and composition in the northern hardwood forest of Northern Michigan. Michigan Agric. Exp. Sta., Tech. Bull. No. 135.

ZILLGITT, W. M. 1948. Optimum economic stocking for northern hardwoods. U.S.D.A. Lake States For. Exp. Sta., Sta. Pap. No. 10. 